\title{
Effectiveness of Natural Herbal Oil Formulation against White Spot Syndrome Virus in Penaeus vannamei
}

Rajeev Kumar Jha*, Yousef Haig Babikian, Haig Yousef Babikian, Soy Daniel Wisoyo, Yuli Asih, Sarayut Srisombat and Benjamin Jiaravanon

PT Central Proteina Prima, Indonesia

\begin{abstract}
The Natural Herbal Oil Formulation (NHOF) have been designed to work against White Spot Syndrome Virus (WSSV) in Shrimp. The essential oil blend extracted from the following plants, Lavandula latifolia, Pinus sylvestris, Jasminum officinale, Citrus limon, Prunus avium, Viola odorata, Gardenia jasminoides, Cocos nucifera, Rosa damascene and Eucalyptus globulus, mixed together to develop as anti-WSSV product. The product were added in the feed, as feed additive. Another product developed which was applied in tank water as water supplement named as "Pondguard" (Reg no. KKP RI no. D16060285-HBC). The Pondguard is composed of three essential oils i.e., Eucalyptus globulus, Pinus sylvestris and Lavandula latifolia. A bioassay trial was conducted to determine the efficacy of developed formulation as an anti-WSSV candidate. The experimental shrimp was fed on NHOF-mixed feed and "Pondguard" applied in the tank water whereas control shrimp were fed on the regular feed. The shrimp of both experimental and control were challenged by WSSV on $15^{\text {th }}$ day of feeding. Two methods of WSSV challenge were applied, per-os challenge and immersion challenge. The cumulative mortality in positive control reached up to $100 \%$ on DPI 10 whereas no mortality appeared in the experimental group and in negative control. The trial results show that the developed natural herbal formulation has significant effect against WSSV in a controlled condition.
\end{abstract}

\section{Introduction}

White Spot Syndrome Virus is the most deadly pathogen of cultured shrimp [1,2]. The cumulative mortality in infetcted shrimp reaches up to $100 \%$ in $4-7$ days in lab and 10-14 days in the ponds [3-6]. The intensity of infection and severity depends on the viral load. The stress factors, like, fluctuation in critical water quality and environmental parameters, like temperature, $\mathrm{pH}$ and Dissolved Oxygen parameters stimulates the process of infection.

Researchers and technicians have been continuously triying to control the spread of White Spot Viral Disease [7]. The limited knowledge on the mode of action and method of application of various agents restricts the success [8]. Various plants in the form of phenolic, polyphenolic, alkaloid, quinone, terpenoid, lectine, and polypeptide compounds etc. have shown anti-viral properties. Various efforts have been made to identify the anti-WSSV properties in the plants, such as, Cynodon dactylon [9,10], Durio zibethinus Murr (Durian) [11] and Ceriops tagal [12] and Eucalyptus spp. and Plelargonium roseum [13].

A successful effort has been made to develop a formulation by adding essential oil blend extracted from ten plants together and mixed it with the feed as feed additive. The feed was supported by a liquid formulation, named as Pondguard, containing three essential oil extract. A trial was conducted to determine the efficacy of feed with Natural Herbal Oil formulation and Pondguard against White Spot Syndrome Virus (WSSV) in Penaeus vannamei [14].

\section{Materials and Methods}

\section{Bioassay lab and glass aquaria}

A bioassay trial was set-up using 10 aquaria each for experimental groups as well as for control groups. The Specific Pathogen Free (SPF)-juvenile shrimp of average weight $0.25 \mathrm{~g}, 10$ in number were maintained in each aquarium. The glass aquaria were cleaned, sun dried and disinfected with $70 \%$ alcohol. Each aquarium was filled with $5 \mathrm{~L}$ of seawater provided with required Dissolved Oxygen (DO) supply.

\section{Water quality parameters}

The seawater utilized during the experiment was gone through the process of sedimentation, filtration and disinfected with $30 \mathrm{ppm}$ active chlorine and finally treated with Ultra Violet radiation (SS-L75W, Matala Water Technology, Taiwan). The water quality parameters maintained during the trial were as followed, Dissolved Oxygen (DO) (>5 ppm), Temperature $\left(27 \pm 1^{\circ} \mathrm{C}\right)$, Salinity (20 ppt), $\mathrm{pH}(7.5-8.15)$ and alkalinity (80-120 ppm).

\section{Experiment start}

The duration of trial was of 30 days i.e., 5 days acclimatization, 14 days feeding, day 15 challenge and from day 16 onwards continues feeding and observation for 10 days. Shrimp of treatment group were fed on experimental feed whereas regular feed was fed to the control. There was no change in feed quality and the rate of feeding throughout the experiment. The liquid supplement, Pondguard was applied on daily basis in experimental tanks throughout the experiment. The shrimp were observed intensively for their behavior and feeding rate and cumulative mortality during the trial.

\section{Shrimp food}

The shrimp feed was produced in Feed Mill of PT. Central Proteina Prima, Indonesia. Treatment group of shrimp was fed on experimental

*Corresponding author: Rajeev Kumar Jha, PT Central Proteina Prima, Indonesia, Tel: +62-21 57851788/206; Fax: +62-21 57851808; E-mail: rajeev.kumar@cpp.co.id

Received September 23, 2016; Accepted October 12, 2016; Published October 17, 2016

Citation: Jha RK, Babikian YH, Babikian HY, Wisoyo SD, Asih Y, et al. (2016) Effectiveness of Natural Herbal Oil Formulation against White Spot Syndrome Virus in Penaeus vannamei. J Pharmacogn Nat Prod 2: 123. doi: 10.4172/24720992.1000123

Copyright: ( 2016 Jha RK, et al. This is an open-access article distributed under the terms of the Creative Commons Attribution License, which permits unrestricted use, distribution, and reproduction in any medium, provided the original author and source are credited. 
feed i.e., CPP regular feed mixed with Natural Herbal Oil Formulation (NHOF) and control group on regular feed. The anti-WSSV NHOF were developed by combining the essential oil blend extracted from the following ten plants, Lavandula latifolia, Pinus sylvestris, Jasminum officinale, Citrus limon, Prunus avium, Viola odorata, Gardenia jasminoides, Cocos nucifera, Rosa damascene and Eucalyptus globulus. Using expeller-pressing method (Anderson International Corporation) performed the oil extractions from the selected plants. The essential oil blends were mixed with the feed in required amount. The basic formulation of both the feed were same except essential oil mixed in the experimental feed.

\section{Pondguard application}

A liquid product called Pondguard (KKP RI no. D 16060285-HBC) was developed as a water supplement. The Pondguard is composed of three essential oils i.e., Eucalyptus globulus, Pinus sylvestris and Lavandula latifolia. It was applied in the treatment tank at the rate of $1.5 \mathrm{ppm}$ on daily basis after tank cleaning and water exchange (approximately $20 \%$ per day).

\section{WSSV disease challenge procedure}

Two kinds of challenge methods i.e., per-os and immersion were applied in the trial [15]. The treatment tanks were divided into two group ( 5 tanks each), one group challenged by per-os method whereas another one by immersion method. The method in detail were as followed,

Challenge method 1: Per-os method of challenge: The muscle to use in per-os challenge was prepared from the artifially WSSV challenged SPF shrimp. The method applied, in short, was pure WSSV viral isolate was injected to the SPF juvenile shrimp. The moribund shrimp with gross sign of WSSV were collected, peeled and de-veined. The muscle were blend and homozenized. The viral load was checked by Real-Time PCR. The collected tissue containing viable WSSV were stored at $-80^{\circ} \mathrm{C}$ by adding sterile glyserol till further use.

On the day of challenge, the shrimp were not fed on artificial feed. The muscle containing WSSV were fed to shrimp at the rate of $5 \%$ MBW as morning meal.

Challenge method 2: Immersion method of challenge: The WSSVcontaminated water was utilized for the immersion challenge. The method applied, in short was, pure WSSV viral isolate was injected to the SPF juvenile shrimp. The dead shrimp with gross sign of WSSV were collected from the tanks after $24 \mathrm{~h}$ of $100 \%$ cumulative mortality. The tank water was filte The viral load was checked by Real-Time PCR (copy number per microliter of water). The $5 \mathrm{~L}$ of WSSV-contaminated water were poured into each experimental and positive control tanks (Table 1).
Post challenge observation: The challenged shrimp were under intensive observation. The feeding rate and tank bottom siphoning schedule and maintained the same for both control and treatment group throughout the experiment. The water exchange was only done in per-os challenged tanks. No water exchange was done in immersion challenged tanks.

Lab confirmation: The WSSV was confirmed by nested PCR analysis.

Statistical analysis: Statistical analysis will be done by ANOVA with $P<0.05$ confidence level (Table 2).

\section{Result and Discussion}

A successful effort was made to develp anti-WSSV product. The product is combination of blend of essential oils with anti-viral properties. The artificial feed as a carrier of anti-viral product is the best way to provide the protection to the shrimp. The extra protection was provided by applying the liquid product in the tank water. It was done with the assumption that the rate of feed consumption will be reduced during the stress condition including at the time of the viral attack. The pondguard was applied on daily to maintain the optimum protection level. The shrimp were fed for first fourteen days to develop enough protection. The feed consumption data in Figure 1 show after the challenge. There was feed drop on DPI 2 and 3 in all the groups which indicates that the challenged animals were under stress. The feed consumption started getting normal from DPI 4 in treatment groups.

Two types of viral challenge methods, per-os and immersion, were applied to test the product at the maximum. The pure WSSV was first used to infect the SPF shrimp and then the tissue of diseased shrimp were utilized for per-os challenge. The tank water containing WSSV were collected from the injection challenged tanks to conduct the immersion challenge. Higher rate of cumulative mortality recorded in immersion challenged positive control group as virus could enter to the shrimp body thorugh the digestive system as well as via osmoregulation. There was no mortality occured in the experimental feed fed groups which showed the anti-viral activities of the product. The mortality started from day 2 of challenge in per-os challenge whereas day 3 in immersion challenge. This could happen due to the variation in viral load as the rate of feeding would vary in the individual shrimp of per-os challenge group (Figure 2).

There was significant difference between experimental group and control group.

The developed product is user friendly as it's mixed and incorporated into the shrimp feed. The developed blended oil extract formulation have shown anti-WSSV properties in the controlled condition.

\begin{tabular}{|c|c|c|c|c|c|c|c|}
\hline \multirow{2}{*}{ Group } & \multicolumn{2}{|r|}{ Challenge } & \multirow{2}{*}{ Rep. } & \multirow{2}{*}{$\begin{array}{c}\text { MBW (g); } \\
\text { Density/5 L }\end{array}$} & \multirow{2}{*}{ Feed } & \multirow{2}{*}{ Pond guard } & \multirow{2}{*}{ Water exchange } \\
\hline & Method & Dose & & & & & \\
\hline \multirow[b]{2}{*}{ Treatment } & $\begin{array}{l}\text { Challenge } 1 \\
\text { Immersion }\end{array}$ & 141.66 copy/uL & \multirow{5}{*}{10} & $0.25 \mathrm{~g} ; 10 \mathrm{pcs}$ & \multirow{2}{*}{$\begin{array}{c}\text { Regular } \\
\text { feed+NHOF }\end{array}$} & \multirow{2}{*}{$\begin{array}{l}\text { Daily; } 1.5 \\
\text { ppm }\end{array}$} & \multirow{5}{*}{$\begin{array}{l}\text {-Pre-challenge } 20 \% \text { per day } \\
\text {-Post-challenge; immersion challenge no } \\
\text { water exchange; per-os challenge } 20 \% \\
\text { water exchange from DPI } 3\end{array}$} \\
\hline & $\begin{array}{c}\text { Challenge } 2 \\
\text { Per-os }\end{array}$ & $\begin{array}{l}\text { WSSV infected tissue at } \\
\text { the rate of } 5 \% \text { of biomass } \\
\text { for } 1 \text { day }\end{array}$ & & $0.25 \mathrm{~g} ; 10 \mathrm{pcs}$ & & & \\
\hline \multirow[b]{2}{*}{ Positive control } & $\begin{array}{l}\text { Challenge } 1 \\
\text { Immersion }\end{array}$ & 141.66 copy/uL & & $0.25 ; 10 \mathrm{pcs}$ & \multirow{3}{*}{ Regular } & \multirow{3}{*}{-} & \\
\hline & $\begin{array}{c}\text { Challenge } 2 \\
\text { Per-os }\end{array}$ & $\begin{array}{l}\text { WSSV infected tissue at } \\
\text { the rate of } 5 \% \text { of biomass } \\
\text { for } 1 \text { day }\end{array}$ & & $0.25 \mathrm{~g} ; 10 \mathrm{pcs}$ & & & \\
\hline Negative control & - & - & & $0.25 \mathrm{~g} ; 10$ pcs & & & \\
\hline
\end{tabular}

Table 1: Experimental design of anti-WSSV trial. 
Citation: Jha RK, Babikian YH, Babikian HY, Wisoyo SD, Asih Y, et al. (2016) Effectiveness of Natural Herbal Oil Formulation against White Spot Syndrome Virus in Penaeus vannamei. J Pharmacogn Nat Prod 2: 123. doi: 10.4172/2472-0992.1000123

Page 3 of 3

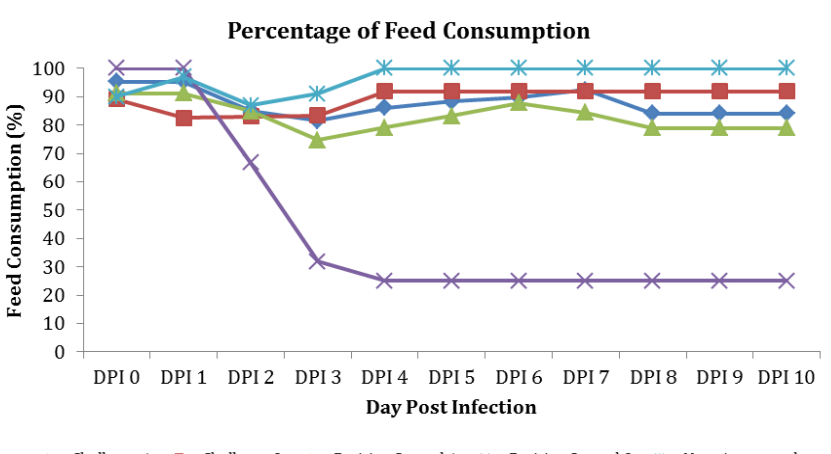

Figure 1: Post challenge feed consumption of experimental and control groups.

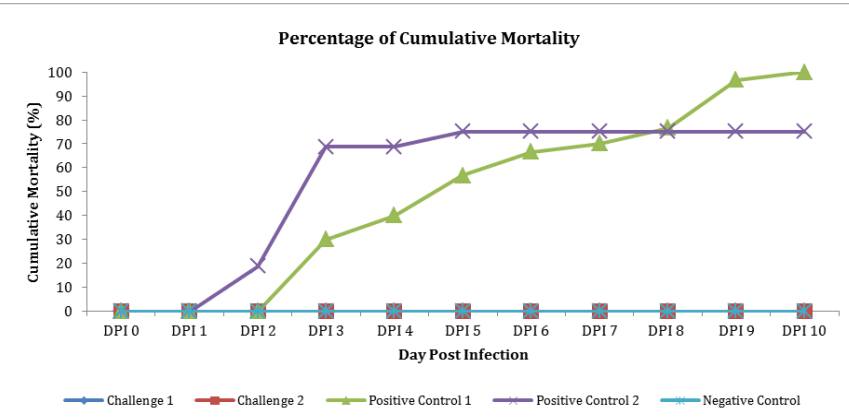

Figure 2: Cumulative mortality percentage of experimental and control shrimp.

\begin{tabular}{|c|c|c|c|c|c|}
\hline Mortality & $\begin{array}{c}\text { Sum of } \\
\text { Squares }\end{array}$ & df & Mean Square & F & Sig. \\
\hline Between groups & 4000.000 & 1 & 4000.000 & 2.667 & 0.141 \\
\hline Within groups & 12000.000 & 8 & 1500.000 & - & - \\
\hline Total & 16000.000 & 9 & - & - & - \\
\hline
\end{tabular}

Table 2: ANOVA test result.

\section{Acknowledgement}

We thank PT. Central Proteina Prima, Indonesia to provide funding for the research.

\section{References}

1. Oseko N, Chuah TT, Maeno Y, Kua BC, Palanisamy V (2006) Examination for Viral Inactivation of WSSV (White Spot Syndrom Virus) Isolated in Malaysia Using Black Tiger Prawn (Penaeus monodon). JARQ 40: 93-97.
2. Sudheer NS, Philip R, Singh BIS (2012) Anti-white spot syndrome virus activity of Ceriops tagal aqueous extract in giant tiger shrimp Penaeus monodon. Arch Virol 157: 1665-1675.

3. Jha RK, Xu ZR, Shen J, Bai SJ, Sun Y, et al. (2006) The efficacy of recombinant vaccines against white spot syndrome virus in Procambarus clarkii. Immunol Lett 105: 68-76.

4. Jha RK, Xu ZR, Pandey A (2006) Protection of Procambarus clarkii against white spot syndrome virus using recombinant subunit injection vaccine expressed in Pichia pastoris. Fisheries Sci 72: 1011-1019.

5. Jha RK, Xu ZR, Shen J, Bai SJ, Sun Y, et al. (2007) Protection of Procambarus clarkii against white spot syndrome virus using recombinant oral vaccine expressed in Pichia pastoris. Fish Shellfish Immunol 22: 295-307.

6. Jha RK, Xu ZR, Iswadi, Alvin T (2010) Vaccine Research against White Spot Virus (WSSV) in shrimp: Challenges and Difficulties. World Aquaculture.

7. Harikrishnan R, Balasundaram C, Heo MS (2011) Impact of plant products on innate and adaptive immune system of cultured finfish and shellfish. Aquaculture 317: 1-15

8. Sivasankar P, Santhiya A, Kanaga V (2015) A review on plants and herbal extracts against viral disease in aquaculture. Journal of Medicinal Plants Studies 3: 75-79.

9. Balasubramanian G, Sarathi M, Venkatesan C, Thomas J, Hameed ASS (2008) Oral administration of antiviral plant extract of Cynodon dactylon on a large scale production against white spotsyndrome virus (WSSV) in Penaeus monodon. Aquaculture 279: 2-5.

10. Balasubramanian G, Sudhakaran R, Syed Musthaq S, Sarathi M, Hameed ASS (2006) Studies on the inactivation of white spot syndrome virus of shrimp by physichal and chemical treatments and seaweed extracts tested in marine and freshwater animal models. J Fish Dis 29: 569-572.

11. Pholdaeng K, Pongsamart S (2010) Studies on the immunomodulatory effect of polysaccharide gel extracted fromDuriozibethinusin Penaeusmonodonshrimpagainst Vibrio harveyiand WSSV. Fish Shellfish Immunol 28: 555-561.

12. Sudheer NS, Rosamma P, Bright Singh IS (2011) In vivo screening of mangrove plants for anti WSSV activity in Penaesus Monodon, and evaluation of Ceriops tagal as a potential source of antiviral molecules. Aquaculture 311: 36-41.

13. Mohamadi M, Zamini AA, Vahabzadeh H (2013) Evaluation of Antibacteria Properties of Eucalyptus spp and Plelargonium roseumExtractsin Common carp, Cyprinus carpio and Their Effectson Blood Indices. Middle East $\mathrm{J} \mathrm{Sc}$ Res 15: 723-731.

14. Valk JM, Flegel BTW, Kou GH, Lightner DV, Lo CF, et al. (2004) Nimaviridae. In: Fauquet CM, MayoMA, Maniloff J, Desselberger U, Ball LA (eds) VIIlthreport of the International Committee on Taxonomy of Viruses. Elsevier, Amsterdam, pp: 187-192.

15. Saulnier D, Haffner P, Goarant C, Levy P, Ansquer D (2000) Experimental infection models for shrimp vibriosis studies: a review. Aquaculture 191: 133-144. 